\title{
A LEI COMO INSTRUMENTO DE PODER DO NAZISMO: UMA ANÁLISE A PARTIR DA CRÍTICA DE FRANZ NEUMANN
}

\section{THE LAW AS AN INSTRUMENT OF POWER OF NAZISM: AN ANALYSIS FROM THE CRITICISM OF FRANZ NEUMANN}

\author{
Aline Andrighetto \\ Bianka Adamatti²
}

\section{RESUMO}

No decorrer da história, verifica-se que a lei tem sido utilizada como objeto de favorecimento dos grupos dominantes. No nacional-socialismo, a legislação assume as vontades do Führer, sendo repleta de cláusulas gerais, atos discricionários e medidas discriminatórias. Franz Neumann por ter vivenciado o período, dedicou-se a criticar vários pilares da estrutura do regime nazista, entretanto neste trabalho somente será abordado o aspecto legal. O objetivo deste estudo é demonstrar a instrumentalização da lei de acordo com os ditames do nacionalsocialismo, sob a crítica do referido autor.

Palavras-chave: Lei; Poder; Nazismo; Crítica; Franz Neumann

\begin{abstract}
Throughout history, it has been verified that the law has been used as an object of favoring the dominant groups. In National Socialism, legislation assumes the will of the Führer, and is filled with general clauses, discretionary acts and discriminatory measures. Franz Neumann for having lived the period, was dedicated to criticize several pillars of the structure of the Nazi regime, however in this work only the legal aspect will be approached. The purpose of this study is to demonstrate the instrumentalization of the law in accordance with the dictates of National Socialism, under the criticism of the author.
\end{abstract}

Keywords: Law; Power; Nazism; Criticism; Franz Neumann

\footnotetext{
${ }^{1}$ Doutoranda em Direito Público pela Universidade do Vale do Rio dos Sinos- UNISINOS. Membro do Núcleo de pesquisa em Direitos Humanos da UNISINOS. Rio Grande do Sul (Brasil). E-mail: bianka.adamatti@hotmail.com

${ }^{2}$ Mestranda em Direito Público pela Universidade do Vale do Rio dos Sinos- UNISINOS. Membro do Núcleo de pesquisa em Direitos Humanos da UNISINOS. Bolsista CNPq. Rio Grande do Sul (Brasil).
} 


\section{INTRODUÇÃO}

A modernidade tem sido testemunha da manipulação das leis em favor dos grupos dominantes. O período registrou legislações essencialmente discriminatórias, recheadas de discursos intolerantes, mascaradas pelo real intuito: a supremacia daquela classe social, a imposição de uma religião em detrimento de outra, e/ou a elevação econômica.

Entre os séculos XV e XVIII, a intolerância na Península Ibérica aos judeus, mouros e cristãos-novos, resultou na criação de uma série de estatutos de pureza de sangue, fruto da intensa propaganda da Igreja Católica. A Inquisição tornou-se a arma legal para a perseguição dos infiéis, que eram torturados, presos e queimados em praça pública, por condutas deicidas. A perseguição foi codificada, atingindo o status de lei nacional.

$\mathrm{Na}$ Revolução Francesa, a liderança burguesa, mascarando suas reais intenções, arrastou as massas para lutar em nome de liberdade, igualdade e fraternidade, derrubando a monarquia e estabelecendo um governo com ideais burgueses. A partir de então, a lei passou a atender às necessidades dessa classe soberana.

No século XX, o partido nacional-socialista chega ao poder, sendo o Führer a representação do Estado, o direito não atende mais à leis universais, curvando-se às vontades do líder e às cláusulas gerais. As legislações estavam repletas de medidas individuais, a segurança jurídica era inexistente, por conta da retroatividade.

Franz Neumann, sendo testemunha da ascensão e queda do regime nazista, critica numa série de trabalhos todos os pilares do nacional-socialismo. Diante disso, o objetivo deste trabalho é demonstrar como a lei foi instrumentalizada em favor do Estado nazista, a partir das críticas de Franz Neumann. Para tanto, o estudo foi dividido em duas partes: a primeira de conotação histórica, a qual demonstra os motivos que fizeram o nazismo ascender ao poder, bem como sua trajetória e importantes medidas legislativas; a segunda trabalhará com o pensamento de Neumann, principalmente no que tange à formação e elementos da lei, demonstrando como o nacional-socialismo trata a legislação. $\mathrm{O}$ método de pesquisa utilizado foi o dialético, através de pesquisa bibliográfica para levantamento de dados históricos e legislações da época trabalhada. 


\section{A ASCENSÃO DO TERCEIRO REICH}

Após a Primeira Guerra Mundial, a Europa enfrentava graves consequências com a ingrata herança do conflito: milhões de baixas humanas e inválidos, além das grandes perdas econômicas com os esforços de guerra. A crise se instalou diante de uma economia fragilizada, acarretando a recessão de diversos Estados europeus. Vários setores sofriam com a desorganização que assolava as nações, fato decorrente da completa destruição de suas lavouras e indústrias (KITCHEN, 2013, p.267).

Porém, o maior efeito da Primeira Grande Guerra, sobretudo para a Alemanha, foram as implicações na reconstrução da política interna, que a partir daí começou a ser pautada nos tratados de paz assinados após o fim dos conflitos, reunidos sob a denominação de Tratado de Versalhes. $^{3}$

A República de Weimar sustentava uma baixa popularidade entre os alemães, onde o fantasma da inflação assombrava. Neste cenário, surge a figura de Adolf Hitler, sob a ideologia do partido nazista, que prometia resgatar as glórias germânicas e combater os inimigos da nação. A população cega pelo nacionalismo acatou as verdades do Partido Nacional Socialista, ajudando a arrastar os judeus para os campos de extermínio, configurando o holocausto ${ }^{4}$, que horrorizou a humanidade (KERSHAW, 2010, p.158).

O Estado alemão buscava a reconstituição de sua glória do passado, por isso o emprego da palavra Reich, como afirma Evans:

3 Trata-se de um texto que visava assegurar a paz e o entendimento entre as nações, elaborado pelos países aliados após o fim da I Guerra Mundial, assinado na Sala dos Espelhos do Palácio de Versalhes, na França, originando assim seu nome. O documento previa a criação da Liga das Nações, (futuramente transformada em Organização das Nações Unidas) a desmilitarização da Alemanha, proibição da indústria bélica, pagamento de duras indenizações de guerra, considerável redução do território alemão em cerca de 10\%, com a devolução de vários territórios. EVANS, Richard J. A chegada do Terceiro Reich. São Paulo: Planeta do Brasil, 2010. p. 104-107.

4 "O termo "holocausto" é originário da palavra hebraica "olá", que siginificava um tipo de oferenda a Deus no Templo de Jerusalém que precisava ser totalmente queimada a fim de expiar um pecado. Quando a Bíblia hebraica foi traduzida para o grego, na chamada Septuaginta, a palavra "olá" foi trazudia de forma acertada, como holokaustos, um composto das palavras holos (inteiro) e kaustos (queimado).[...] O escritor Elie Wiesel é apontado como um dos responsáveis pela aplicação desse termo, nos anos 1950, ao massacre da Segunda Guerra Mundial, numa referência aos crematórios nazistas. O termo tornou-se desde então o mais usualmente utilizado, porém a sua adoção traz problemas teológicos: se os judeus foram um sacrifício queimado, implicitamente os nazistas seriam uma espécie de sacerdotes, envolvidos numa missão divina. Também implica que existiu algum pecado do povo judeu que motivou o massacre. Daí uma parcela significativa dos especialistas e também do público geral preferir uma palavra alternativa: Shoá. Na Bíblia, a palavra significa "destruição total que acomete um indivíduo ou o coletivo de forma repentina e inesperada, provocando choque". No contexto bíblico, o termo também carrega um elemento de punição por pecados, mas seu uso após a Segunda Guerra Mundial desconsiderou esse elemento." FINGUERMAN, Ariel. A teologia do Holocausto: como os pensadores judeus e cristãos explicaram Auschwitz. São Paulo: Paulus, 2012. p. 11-12. 
A palavra Reich evocava entre alemães cultos uma imagem que ressoava muito além das estruturas institucionais criadas por Bismarck: o sucessor do Império Romano; a visão do Império de Deus aqui na terra; a universalidade de sua reivindicação de suserania; em um sentido mais prosaico, mas não menos poderoso, o conceito de um Estado germânico que incluiria todos de língua alemã na Europa central - "um Povo, um Reich, um Líder", como viria a propor o slogan nazista (grifo do autor) (2010, p.44).

O Primeiro Reich foi considerado o Império Romano do medievo e o Segundo Reich, aquele formado por Bismarck após a unificação alemã no ano de 1871, depois de derrotar a França e humilhá-la em sua casa, o Palácio de Versalhes, o que seria vingado posteriormente com o final da Primeira Guerra Mundial e a derrota da Alemanha (SHIRER, 1967, p.147). A população alemã buscava aquele que fosse dar continuidade à glória, um führer (líder) para construir um Terceiro Reich (KITCHEN, 2009, p.65).

\subsection{Os Instrumentos e Justificativas dos Nazistas}

A República de Weimar acarretava a insatisfação do povo alemão, por conta disso, a propaganda nazista se aproveitava utilizando slogans que incentivasse o resgate das vitórias germânicas conquistadas pelos seus antepassados. Segundo Stackelberg (2002), todo esse discurso era apoiado pela crise moral e econômica que a Alemanha amargava durante toda a década de 20, que já afundada nas dívidas de guerra, entrou em total colapso com as duras dívidas impostas pelo Tratado de Versalhes, culminando com a crise de 1929 (2002, p. 102).

O crash da bolsa findou com a confiança alemã depositada no liberalismo político e econômico que ainda restava entre os cidadãos de classe média, mexendo também com o eleitorado, acreditando que somente uma ousada e potencializada medida poderia salvar a crise instalada. A escolha dos trabalhadores pelo Partido Comunista (KPD) crescia, entretanto o maior número de votos era representado pela classe média que depositava, pela primeira vez, a confiança no partido nazista (WISTRICH, 2002, p.77).

A ideologia nazista, essencialmente nacionalista, racista e moralista, influenciada pelos acontecimentos históricos recentes, conquista seu espaço entre os cidadãos, e aqueles que antes desconfiavam ou contrariavam, passam a analisá-la através de outra perspectiva. Com isso, os preceitos do partido nacional-socialista fixam raízes nos descrentes na República de Weimar, transformando a Alemanha, na ditadura de Hitler (EVANS, 2010, p.548-549).

\subsection{O Início do Fim: A Ascensão de Adolf Hitler}


Os líderes empresariais estavam convencidos que somente a inclusão de Hitler no governo poderia restaurar a economia e a ordem política, evitando o deslocamento do apoio à esquerda, onde os comunistas cada vez mais agregavam votos. Hindenburg que possuía certa relutância em aceitar Hitler no governo, pois o considerava de origem inferior, um homem simples do campo, sem outra escolha e apreensivo com a ameaça comunista, foi convencido da nomeação do líder nazista a chanceler, o que ocorreu em 30 de janeiro de 1933 (KITCHEN, 2013, p.332-333).

Finalmente a estratégia planejada por Adolf Hitler de ascender ao poder através das urnas e meios legais obteve êxito (EVANS, 2010, p.541). Os apoiadores do partido nazista celebraram a ascensão ao poder com uma marcha de tocha, o que despertou quase que instantaneamente o nacionalismo escondido nos alemães, pois já no dia $1^{\circ}$ de fevereiro de 1933, Hitler discursou ao povo alemão falando de moral, importância da família e proteção ao cristianismo, afirmou que era necessário restaurar no povo, ignorando as classes sociais, a consciência da união nacional, buscando a glória dos seus antepassados (CLARET, 2011, p.51).

No dia 4 de fevereiro, o novo chanceler havia expedido um decreto de emergência, justificado pela proteção do povo alemão, concedendo autoridade ao governo para censurar a imprensa e restringir o direito de reunião dos comunistas. Para Kitchen (2010), além de afetar diretamente os esquerdistas, eliminando a sua imprensa, mesmo que unilateralmente, induziu a mídia geral a praticar a autocensura, evitando as críticas ao governo atual (2009, p.87).

Em 27 de fevereiro, com o incêndio do prédio do Reichstag, Hitler assinou um decreto, com as alegações da proteção do Estado alemão, decretando estado de emergência em toda nação. Os direitos constitucionais, as liberdades civis e a privacidade das comunicações estavam comprometidas, em um sinal de que uma ditadura começava a se instalar (KITCHEN, 2009, p.88).

O incêndio ao parlamento alemão foi atribuído ao levante comunista, porém sempre houveram desconfianças de que os próprios nazistas foram os responsáveis, a fim de terem uma justificativa para a perseguição. Os nazistas passaram a prender de maneira desenfreada, o que causou superlotação nas penitenciárias (EVANS, 2010, p.407-408). Para tanto, a solução foi a construção do primeiro campo de concentração oficial, em Dachau, a poucos quilômetros de Munique, logo em março de 1933. O objetivo, segundo Gellately (2011), era a reeducação dos presos políticos e outros seres malvistos na sociedade alemã (2011, p.50-51). 
No dia 23 de março de 1933, o Reichstag aprovou a Lei de Supressão do Sofrimento do Povo e do Reich, a chamada Lei Plenipotenciária ou de Exceção, que concedia plenos poderes ao chanceler, tanto legislativos, quanto executivos, pelo prazo de 4 anos. Depois desse evento, o parlamento alemão foi dissolvido (EVANS, 2010, p.428-429). No mês de novembro do mesmo ano, ocorreu uma eleição onde o partido nazista figurava como chapa única. O Reichstag passou a ser elemento meramente decorativo da política alemã, pois aprovava tudo sem a menor contestação. Prorrogou a Lei Plenipotenciária por mais 4 anos, em 1937, e novamente em 1941. Como havia a ilusão da legalidade nos atos dos deputados, a Alemanha transformou-se em ditadura de forma legal (KITCHEN, 2013, p.339-340).

A Lei de Restauração do Serviço Público Profissional, aprovada em 7 de abril de 1933, determinava que fossem dispensados todos os comunistas, simpatizantes de esquerda, e todos os não-arianos. Isso envolveu uma exclusão em massa das posições influentes estatais e da sociedade, já que judeus e todos aqueles contrários ao nacional-socialismo deveriam ser afastados de seus cargos (GELLATELY, 2011, p.56). A medida foi agravada com a expulsão até de pessoas que eram casadas com não-arianos. Menciona Evans (2010), que as instituições de ensino foram diretamente afetadas, pois muitos dos cientistas e estudiosos eram de origem judaica, como Albert Einstein (2010, p. 461-462).

Com a morte do presidente Hindenburg, em 02 de agosto de 1934, Hitler expediu um decreto em que fundia os cargos de presidente e chanceler, não havendo oposição. Em 19 de agosto, na forma de plebiscito o líder nazista recebeu indiscutível resultado afirmativo, sendo seus poderes ratificados e apoiados pela nação alemã (KITCHEN, 2013, p.350). A República de Weimar, com o falecimento do presidente havia sido substituída por um novo regime autoritário, com o intuito de resgatar as glórias alemãs e acima de tudo visando o nacionalismo exacerbado. No ano de 1935, a suástica do Partido Nazista, já estampava todo o país, tornando-se a bandeira oficial alemã (STACKELBERG, 2002, p.166-167).

O nacionalismo latente que a cada dia se intensificava por todo o território do Reich, acarretou a obsessão pela higiene racial. Os alemães atribuíam a derrota na Primeira Guerra Mundial à raça impura que havia composto as linhas de frente. Segundo Kitchen (2009), a solução para uma iminente guerra, que se aproximava seria a purificação da raça (2009, p.116-117), através da política de eugenia. ${ }^{5}$

\footnotetext{
5 "Aqueles que deveriam ter sido eliminados por seleção natural sobreviveram, de modo que o material genético dos fortes e superiores naturais era ameaçado pelo dos naturalmente fracos e inferiores. Portanto, aqueles considerados inferiores deveriam ser impedidos de procriar, se necessário por meio de esterilização compulsória e, em casos extremos, por eutanásia. A Medicina, devia, enfim não só zelar pela saúde do
} 
Sob o argumento de purificação do sangue alemão, uma série de normas profiláticas de caráter eugênico foram expedidas. O casamento, por exemplo, só fora permitido após minuciosos exames médicos e eugênicos. Também foram tomadas medidas a fim de impedir a reprodução dos considerados inaptos, como a castração de delinquentes e a esterilização de deficientes hereditários. O órgão que ordenava as castrações era o Tribunal Penal; o órgão que determinava as esterilizações era especializado para este fim, com sentença executória. Os tribunais ampliaram de uma forma mórbida a lei de esterilizações, sendo contabilizadas mais de 50.000 mortes de deficientes mentais (NEUMANN, 1943, p.137-138).

Os judeus gradativamente passaram a ser boicotados da sociedade. Além da Lei de Restauração do Serviço Público Profissional, os judeus foram excluídos de todos os campos de atuação de trabalho, educação, indústria, jornalismo e economia. O governo excluiu médicos e dentistas dos planos de saúde, perdendo o direito de tratarem seus pacientes pelo sistema nacional de saúde. No setor agrícola, houve a proibição de possuírem terras e negociarem gado. Os estudantes de origem judaica recebiam gravosas medidas a fim de restringirem o acesso às universidades e escolas secundárias (STACKELBERG, 2002, p. 203204).

Promulgadas em 15 de setembro de 1935, as Leis de Nuremberg escancararam de vez a eliminação da influência judaica no Estado alemão. No início de setembro, não satisfeito com os decretos anteriores e a diminuição do espaço judeu na sociedade, Hitler decidiu que era hora de impor-lhes maiores restrições, com o intuito de que deixassem o Espaço Vital alemão, traduzindo todo o antissemitismo ínsito às leis nazistas, como aponta Bryan Mark Rigg (2003), sobre a Lei para a Proteção do Sangue e Honra Alemães:

As leis emitidas em 15 de setembro de 1935, aprovadas pessoalmente por Hitler, privavam os judeus de cidadania, proibiam as casas judias de ter criadas alemãs, proibiam qualquer alemão de casar-se com um judeu e proscrevia as relações sexuais entre judeus e alemães. Estas leis impuseram uma nova moral aos alemães (2003, p.119-120).

A Lei de Cidadania do Reich reduziu os judeus alemães à situação de estrangeiros, excluindo-os de seus direitos políticos. Segundo a primeira Lei de Nüremberg, os judeus alemães não eram mais alemães, ou seja, os judeus passaram a ser párias da sociedade (ARENDT, 1987, p.180). O conceito de pária utilizado pela primeira vez por Max Weber é 
repetido por Hannah Arendt:

Ceux qui ont expérimenté l'ambiguïté de la liberté de l'émancipation, et encore plus celle de l'ídentité de l'assimilation, prirent clairement conscience du fait que le destin des juifs en Europe n'était pas seulement celui d'un peuple opprimé, mais également celui d'un peuple paria selon la formule de Max Weber. Cette situation sociale de parias en vertu de laquelle, à titre d'individus, ils demeuraient extérieurs à la société, reflétait le statut politique du peuple tout entier. ${ }^{6}$

Além disso, os judeus não poderiam oferecer a famosa saudação ao führer - heil Hitler -, demonstrar qualquer participação na sociedade alemã, até mesmo hastear a bandeira alemã. Como a lei era omissa, no que tange à definição de quem é considerado judeu, menciona Stackelberg (2002), que para sanar dúvidas, em novembro de 1935, foi emitida uma nota sobre as Leis Raciais de Nuremberg,

[...] definindo um judeu como qualquer pessoa que descendesse de pelo menos três avós judeus (em contraste com a Lei do Serviço Público, que definia "não-arianos" como aqueles que descendiam de um ou mais avós judeus). Pessoas com apenas dois avós judeus eram classificadas também como judeus, como se pertencessem à comunidade religiosa judaica ou fossem casados com judeus. (STACKELBERG, 2002, p.205, grifo do autor).

Ainda, após o desenvolvimento dos padrões raciais, na forma de lei, mesmo quem apresentasse o mínimo resquício de descendência judaica, era considerado judeu, pois no caso de dúvida, era melhor que o indivíduo fosse classificado como judeu, pois havia herdado o sangue dos sionistas (STACKELBERG, 2002, p.205).

Aqueles que apresentavam origem mista possuíam classificação diferenciada, os que não pertenciam à religião judaica e não eram casados com judeus, mas possuíam dois avós judeus eram chamados de "mischling de primeiro grau”; para ser categorizado como “mischling de segundo grau”, a pessoa só possuía um avô judeu. Era necessário que houvesse o consentimento para que o de primeiro grau casasse com o de segundo grau ou um alemão. $\mathrm{O}$ casamento entre dois de primeiro grau era permitido, e com judeus também, porém neste último caso, ele perderia o status de mischling de primeiro grau, e seria considerado judeu. Para os mischling de segundo grau, não havia necessidade de permissão para se casar com um

\footnotetext{
6 "Aqueles que experimentaram a ambigüidade da liberdade da emancipação, e ainda mais, a identidade da assimilação claramente tomou conhecimento de que o destino dos judeus na Europa não era apenas a de um povo oprimido, mas também, a de um pária como afirma Max Weber. Este status de pária social, fazem com que sejam excluídos da sociedade, refletindo no status político de todo o povo judaico." (ARENDT, 1987. p. 180).
} 
alemão, porém estava proibido de se casar com um judeu ou mischling de primeiro grau (WISTRICH, 2002, p.88).

As Leis de Nüremberg tiveram consequências diretas para os governos regionais e municipais, incentivando-os a adotarem outras posturas discriminatórias, como a proibição de judeus frequentarem locais públicos, como piscinas, cinemas e parques. A população a cada dia observava os judeus como um problema da nação e de toda forma também os excluíam, mesmo com posturas que não estavam previstas em lei, como cartazes fixados em pequenos estabelecimentos com a proibição da entrada de judeus e animais. Menciona Stackelberg (2002), que mesmo as pessoas que eram amigas de judeus, sentiam-se pressionadas pelas medidas do governo e repúdio público, abandonando qualquer contato e, optando no caso de cônjuges, pelo divórcio (STACKELBERG, 2002, p.206).

A situação do povo judaico a cada dia ficava mais difícil, com o surgimento de muitas restrições. Professores judeus foram proibidos de ensinar alunos alemães, os estudantes judeus estavam proibidos de se formarem em qualquer área em universidades alemãs. Segundo Kitchen (2013), em 1937 os judeus foram condenados por cometerem relações sexuais com alemães, e posteriormente ao cumprimento da sentença de prisão, seriam levados para campos de concentração $(2013$, p.363).

O ano de 1938 foi intensificado por novas legislações de caráter antissemita, como o decreto de 17 de agosto referente aos nomes de judeus. A fim de que fossem prontamente identificados, pais arianos foram proibidos de registrarem seus filhos com nomes judeus (segunda uma lista), assim como pais judeus não poderiam registrar os recém-nascidos com nomes arianos. O intuito do governo nazista era que os judeus deixassem a Alemanha, e quem permanecesse deveria ser isolado socialmente e identificado. Para isso, as autoridades fronteiriças carimbavam a letra "J" nos passaportes de judeus alemães, para controle de saída do país (NEUMANN, 1943, p.141).

\section{A LEGISLAÇÃO NAZISTA SOB O OLHAR DE FRANZ NEUMANN}

O Regime nazista inicialmente assumiu a identidade tradicional de direito, com juízes e tribunais organizados. Entretanto, nos primeiros meses de 1933, havia sinais ameaçadores de que o Reich estava abandonando a Rechtsstaat ${ }^{7}$, juízes, notários e advogados judeus foram demitidos, leis penais foram endurecidas, o princípio "não há crime sem lei anterior" foi

\footnotetext{
${ }^{7}$ Tradução livre: Estado de Direito.
} 
abolido, comunistas foram enviados para campos de concentração. $\mathrm{O}$ assassinato em massa de inimigos políticos passou impune. Hitler proclamou uma lei declarando que os assassinatos eram "atos de defesa nacional, portanto dentro da legalidade" (STOLLEIS, 1998, p.2). A partir de então, "o verdadeiro direito passa a ser ou a ordem do Führer ou a cláusula geral" (NEUMANN, 2014, p.47).

A estrutura jurídica nazista impregnou o ordenamento jurídico de cláusulas gerais e abertas, o que dá margem para decisões discricionárias (NOBRE, 2008, p.100). As cláusulas gerais são caracterizadas por uma falsa generalidade, mesmo sendo formuladas com o emprego de termos gerais, ampliam o debate, dando liberdade de ação para o executivo tendo em vista que muitas questões não estão previstas em lei (NEUMANN, 2014, p.6).

Neumann afirma que as cláusulas gerais estão presentes no momento em que o Estado confronta grupos de poder significativos. Sempre que um partido poderoso estiver no poder, diante de outros menores ou do Estado, o direito racional não deve ser mais aplicado, recorrendo-se às cláusulas gerais (NEUMANN, 2014, p.68).

Para a construção de uma lei, deve-se atentar para três elementos relevantes: a lei deve ser geral na construção da proposição, ser universal, e não ter força retroativa. Para justificar os dois primeiros elementos, Neumann utiliza a formulação de Rousseau constante no seu Contrato Social:

Quando eu digo que o objeto das leis é sempre universal, entendo que a lei considera os súditos como coletividade e suas ações como abstratas e que nunca entende uma pessoa como indivíduo particular ou leva em conta uma ação individual. Assim, a lei pode muito bem estatuir a existência de privilégios, mas nunca pode conceder um privilégio nomeadamente a uma pessoa... em uma palavra: toda afirmação que se refere a um objeto individual não pertence ao poder legislativo (ROUSSEAU, apud NEUMANN, 2014, p.25).

Portanto, a legislação não é somente o instante em que algo é expresso como regra geral para todos, mas o momento interno, como definir o conteúdo da dita universalidade. As proposições jurídicas fundamentais (Rechtsgrundsätzen) ou cláusulas gerais são aquelas que não possuem um conteúdo claro, como por exemplo, legislações que indicam termos como bons costumes, imoral, sentimento popular. Normalmente, representam termos abstratos, de difícil esclarecimento, pois na sociedade atual, não há unanimidade sobre o que é contrário aos costumes. Um Estado que constrói sua legislação através de cláusulas gerais, mascara medidas individuais. Por outro lado, há também as leis que excluem do seu texto normativo 
remissões a ordenamentos morais, que de fato universalizam o seu conteúdo, como: "a capacidade jurídica das pessoas começa com a conclusão do nascimento ( $\$ 1^{\circ}$ do Código Civil Alemão)" (NEUMANN, 2014, p.27). A lei geral deve conter o mínimo de determinação material, para assim, garantir a independência necessária para o juiz decidir, sem se curvar às vontades exclusivas do soberano.

Além da universalidade, a lei geral não deve ser retroativa, pois aquela lei que cabe retroatividade, também passa a ser individual, pois os fatos concernentes àquela norma já existem, antes de sua formulação. A Alemanha do século XVIII proibiu a retroação da lei, mas apenas ao juiz, o que significa que não impediria o legislativo de criar legislações retroativas. As legislações do código penal alemão também não poderiam retroagir, por questões éticas. No Terceiro Reich, os advogados nazistas declararam que o princípio nulla poena sine lege é oriundo do direito romano, portanto não aplicável ao direito alemão, essa declaração (do caráter não-alemão do princípio da não-retroatividade), tinha o intuito de fundamentar a Lei Van der Lubbe, que introduziu de maneira retroativa a pena de morte ${ }^{8}$ para alguns crimes. De acordo com Neumann (2010) e Müller (2009), cerca de vinte outras leis e decretos contendo a aplicação de penas retroativas, também foram promulgadas.

A lei também regula fatos relativos às instituições ou liberdades humanas. Neumann classifica a liberdade em "quatro verdadeiros direitos de liberdade" (Freiheitsrechte). Os direitos de liberdade pessoal, que, por exemplo, indica que um homem não pode ser preso sem fundamento e devido processo legal. Há também a liberdade de domicílio, a liberdade de correspondência, e os direitos políticos de liberdade, que nesse caso incluem a participação do Estado, é o caso da livre associação. Estes são tanto liberais, quanto democráticos, pois a liberdade é garantida pelo órgão estatal. Também há os direitos econômicos de liberdade. Para Neumann, as constituições não garantem esses direitos de forma ilimitada, ou seja, se necessário restringi-los, será com fundamentos em leis (2014, p.28-29).9

Os tribunais ingleses, contrariando sua conduta tradicional, certa vez, trataram uma medida individual como lei, suspendendo liberdades individuais garantidas no texto legal, como o habeas corpus. O caso paradigmático consiste na privação de liberdade de um nativo norte-americano, demonstrando que, a lei universal pode ser manejada de acordo com os

\footnotetext{
${ }^{8}$ Não há certeza do número de pessoas vítimas da pena de morte, entretanto estima-se que gire em torno de 5.266. (RACHLIN, 2013. p. 65).

9 A lei geral também tem poder sobre as instituições humanas, como fundações, empresas, casamentos, e principalmente a propriedade privada dos meios de produção, que está conectada a uma série de liberdades, como a relativa aos direitos econômicos. NEUMANN, Franz. A mudança de função da lei no direito da sociedade burguesa. Revista Brasileira de Estudos Políticos, Belo Horizonte. n. 109. p. 29, jul/dez. 2014
} 
interesses do grupo de poder (NEUMANN, 2014, p.36-37).

Kant recepciona a teoria de Montesquieu e Rousseau ao exigir que o órgão estatal governe com leis universais, o que até o final do século XIX tornou-se uma reivindicação dos estudiosos da teoria do direito alemã. Montesquieu, influenciado por Descartes através da mediação de Malebranche, no Espirit des lois, é claro ao afirmar que o Estado deve governar através de leis gerais. Rousseau e Montesquieu influenciaram também a Revolução Francesa, tendo a Declaração dos Direitos do Homem e do Cidadão incluído a ideia da universalidade da lei. Entretanto, para Neumann no final do século XIX, a generalidade da lei é substituída pela separação entre lei formal e material (2014, p.34-35).

Menciona:

Lei formal é toda expressão da vontade estatal; lei material é apenas uma expressão da vontade estatal que contenha uma proposição jurídica, ou seja, que produza direitos e deveres subjetivos. Nesse sentido, a lei orçamentária não é material, uma vez que contém apenas uma autorização para que o Estado possa realizar despesas nos limites do orçamento. Essa teoria dualista foi amplamente aceita pela ciência jurídica alemã (NEUMANN, 2014, p.3536).

Uma teoria de estruturação da lei remete a uma sobre o posicionamento do juiz perante ela, pois quando a lei impera, a tarefa do magistrado é meramente cognitiva, como diria Montesquieu, o juiz é a boca da lei. Sendo assim, o liberalismo configura-se como um sistema fechado e sem lacunas para interpretação, esta forma de positivismo na Alemanha ficou conhecida como interpretação dogmática. De forma alguma, o magistrado pode criar uma legislação, ou até mesmo fazer comentários, e se achar algum erro ou lacuna, deve informar o legislativo, tanto que em 1780, Frederico II da Prússia proibiu a "interpretação das leis contra a letra e o contexto das palavras" (NEUMANN, 2014, p.40).

O princípio da divisão de poderes e a lei também têm função ética, a qual ganhou expressão, após a filosofia do direito de Rousseau. Assim, a universalidade da lei e a independência do magistrado garantem as liberdades pessoais e políticas. Para Neumann (2014, p.46), "a liberdade apenas é garantida quando intervenções como essas puderem ser reduzidas à lei universal e, assim, quando o princípio da igualdade for garantido”.

As mudanças são introduzidas através da lei, o que explica a concorrência pelas cadeiras legislativas. A burguesia alemã possuía um papel importante no processo legislativo, pois dominava de forma maciça o Parlamento, consequentemente, levando seus objetos de interesse para a norma legal. No nazismo, a soberania do parlamento foi extinta, dando total 
autonomia ao partido chegar ao poder, sendo o Direito e o Führer, um só.

Hitler acreditava que a burocracia era incompatível com os objetivos do partido, pois se guiou por métodos legais, seguindo regras fixas e conservando o mínimo de liberdade e segurança, apoiando-se na máxima que todo direito racional, independente do conteúdo, terá uma função protetora. A rejeição pela soberania do Estado, na realidade, mascara o verdadeiro intuito: a eliminação do direito racional (NEUMANN, 1943, p.102-103).

O Führer confere forma e caráter às leis, decretos e decisões, protege o Direito, e quando há necessidade intervém nele, de maneira executiva. Como demonstrado anteriormente, o princípio da não-retroatividade não é mais reconhecido; leis individuais, com caráter de privilégio (e perseguição a certos grupos) foram promulgadas; também não há mais o princípio basilar do Rechtsstaat, a igualdade do sujeito perante a lei. O Direito passa a ser um mero instrumento nas mãos dos nazistas para a concretização de seus objetivos.

A lei é um artifício para obtenção do poder pela classe dominante, como é o caso das leis do nacional-socialismo. Toma-se como exemplo, as Leis de Nüremberg (1935), que representava um dos pilares da ideologia do partido, o antissemitismo, como demonstra uma delas, a Lei de Proteção ao Sangue e Honra Alema $\tilde{a}^{10}$ de 15 de setembro de 1935:

Plenamente convencido pelo conhecimento de que a pureza do sangue alemão é essencial para a existência continuada do povo alemão, e animado pelo desejo inflexível de salvaguardar a nação alemã por todo o futuro, o Reichstag decidiu unanimemente aprovar a lei abaixo, por este ano promulgada.

Seção 1 - (1) São proibidos casamentos entre Judeus e nacionais de sangue alemão ou assemelhado. Os casamentos celebrados em desacordo com a presente são nulos, mesmo se, com o propósito de evitar esta lei, forem concluídos no exterior.

(2) Somente o Promotor Público pode iniciar processos de anulação.

Seção 2 - São proibidas as relações sexuais entre Judeus e nacionais de sangue alemão ou assemelhado.

Seção 3 - Não será permitido aos Judeus ter como empregadas domésticas mulheres de sangue alemão ou assemelhado.

Seção 4 - (1) É proibido aos Judeus hastear a bandeira do Reich e nacional e exibir as cores do Reich.

(2) Poderão por outro lado exibir as cores judaicas. O exercício dessa autoridade é protegido pelo Estado.

Seção 5 - (1) - Uma pessoa que agir em desacordo com a proibição contida na Seção 1 será punida com trabalhos forçados.

(2) Uma pessoa que agir em desacordo com a proibição contida na Seção 2 será punida com prisão ou com trabalhos forçados.

(3) Uma pessoa que agir em desacordo com a proibição contida na Seção 3 ou 4 será punida com prisão de até um ano e com uma multa ou uma dessas

\footnotetext{
${ }^{10}$ Referida na primeira parte do trabalho.
} 
penalidades.

Seção 6 - O Ministro do Interior do Reich em concordância com o representante do Führer emitirão os regulamentos legais e administrativos necessários para a implementação e suplementação desta lei.

Seção 7 - Esta lei entrará em vigor no dia seguinte à promulgação, exceto pela Seção 3, que entrará em vigor apenas em $1^{\circ}$ de janeiro de 1936 (LACERDA, 2012, p.68-69).

A referida lei é um claro exemplo de desigualdade formal, nesse caso justificada pela busca da raça pura alemã, segregando um grupo, tolhendo seus direitos de liberdade em nome do poder. Pode-se observar também, a aplicação das cláusulas gerais, onde é verificada sua relação com ordens de valor extrajurídicas, de acordo com os princípios do nacionalsocialismo, destruindo os limites do Poder Judiciário, desembocando em decisões políticas.

A livre interpretação (de acordo com a ideologia do Reich) feita pelos tribunais ocorreu no exemplo de definição de relação sexual, quando questionadas todas as formas de contato que tenham conotação sexual. Até mesmo uma interpretação ampla não era o suficiente para alguns tribunais, devendo ser verificada a vontade do legislador, que considerava ilegal toda e qualquer forma perversa de relação entre um judeu e cidadão de sangue alemão. Segundo Müller (1992, p.100-101), o Supremo Tribunal estimulava os tribunais menores a interpretar a vontade do legislador além da letra fria da lei, consequentemente, abrindo possibilidades inimagináveis. Neste sentido,

Para um Tribunal de Hamburgo, os beijos de um homem impotente "assumiam o lugar da relação sexual normal" e resultavam em uma sentença de dois anos. A massagem terapêutica, nem é preciso dizer, muito cedo ficou sob suspeita, como revela o notório caso do comerciante judeu Leon Abel. Embora a terapeuta de "sangue alemão" negasse categoricamente que Abel tivesse mostrado qualquer sinal de excitação sexual durante aquela única sessão de massagem e embora, durante seu julgamento, o próprio Abel recuasse da confissão que havia feito a Gestapo, o tribunal condenou a dois anos, "por ter alcançado satisfação sexual com a senhorita M., com isso 'efetuando' o crime de desonra de raça, quer ou não a testemunha tivesse conhecimento disso.” (FRIEDLÄNDER, 2012, p.221, grifo do autor.).

Inúmeras leis individuais foram promulgadas, como a determinação de um funeral estatal para o Presidente Hindenburg; a isenção de impostos para a propriedade fundiária do mesmo presidente e seus descendentes, e também para o marechal Mackensen. Acerca do princípio da não-retroatividade, Neumann (2010, p.472), menciona que no dia 3 de julho de 1934, a lei legalizou todas as medidas para findar com a Revolta de Roehm, "declarou um ato precedente ilegal, mas tornou legal um crime já cometido”, nunca antes na história havia 
acontecido isto. As leis retroativas, segundo o autor, procuram derrubar os inimigos políticos, ou legalizar as medidas consequentes do período de transição (2010, p.473).

Com todo maquinário jurídico, unido a legislativo e executivo, funcionando sob o controle de um só, do líder supremo da nação, é impossível pensar em Direito como um instrumento de mudanças sociais. No nazismo, não há lei universal, a lei é a vontade do Führer, o Direito do nacional-socialismo é um emaranhado de normas soltas, de caráter individual, discriminatórias e pensadas para favorecer o partido de acordo com a situação.

\section{CONCLUSÃO}

A necessidade de uma lei escrita surge no fim da Idade Média, para formalizar a diferença entre fiéis e infiéis, seguindo as diretrizes dos ditames canônicos. Desde então, o Direito passou a ser instrumento para concretização do poder dos grupos dominantes. A história é testemunha de séculos de opressão aos chamados grupos minoritários (afrodescendentes, ciganos, judeus, homossexuais, mulheres, etc), formalizada através da positivação no texto legal.

No Direito nazista a irracionalidade passa a ser lei, a ideologia, carregada de preconceito, é legisladora. A incoerência é vista como algo natural dentro do sistema jurídico, devendo o cidadão comum se curvar, e o pária ser perseguido. Todo o sistema foi construído friamente como uma máquina de eliminação de indesejados, seja através da eugenia, ou das câmaras de gás. Por ser essa aberração, que Neumann o compara com a figura do Behemoth, o monstro da escatologia hebreia, que traz ao mundo o caos, da mesma forma que o nacionalsocialismo, que retira o direito e a dignidade humana das pessoas, instaurando o medo e transformando o Estado em um não-Estado.

$\mathrm{O}$ degenerado Estado nacional-socialista não foi enterrado no século $\mathrm{XX}$, várias características vistas no Reich, podem ser observadas atualmente. O final da guerra e o reconhecimento universal dos direitos humanos inaugurou um novo momento, em que se fala na superação do positivismo, ou seja, um pós-positivismo, o qual se propõe a ser o oposto do modelo visto no regime nazista. Neste âmbito, normas discriminatórias e com cláusulas abertas são rechaçadas, devendo haver um julgamento fundamentado e sem juízos discricionários. Entretanto, mesmo no séc. XXI, ainda podem ser observados corpos normativos com essência segregatória, como é o caso do Estado de Israel, que aplica medidas semelhantes às das Leis de Nüremberg concernente aos judeus, aos palestinos. 
Já no cenário político brasileiro a câmara legislativa atua em prol de seus interesses pessoais. A bancada evangélica legisla seguindo preceitos religiosos e morais, abastecendo os projetos de lei de discursos intolerantes e preconceituosos. A latifundiária pressiona o executivo sobre a decisão de demarcações de terras indígenas, tendo em vista a perda do poderio econômico, caso aprovadas. O judiciário, muitas vezes, abarca decisões discricionárias de seus magistrados, não as fundamentando ou agindo de acordo com princípios morais, resultando em decisões políticas, o que fere os preceitos democráticos do Estado de Direito.

\section{REFERÊNCIAS}

ARENDT, Hannah. La tradition cachée: le juif comme paria. Paris: Christian Bourgois, 1987.

CLARET, Martin. Hitler por ele mesmo. São Paulo: Martin Claret, 2011.

EVANS, Richard J. A chegada do Terceiro Reich. São Paulo: Planeta do Brasil, 2010.

FINGUERMAN, Ariel. A teologia do Holocausto: como os pensadores judeus e cristãos explicaram Auschwitz. São Paulo: Paulus, 2012.

FRIEDLÄNDER, Saul. A Alemanha Nazista e os Judeus: anos de perseguição, 1933-1939. v.1. São Paulo: Perspectiva, 2012,

GELLATELY, Robert. Apoiando Hitler. Rio de Janeiro: Record, 2011.

KERSHAW, Ian. Hitler. São Paulo: Companhia das Letras, 2010.

KITCHEN, Martin. História da Alemanha Moderna: de 1800 aos dias de hoje. São Paulo: Cultrix, 2013.

KITCHEN, Martin. O Terceiro Reich: carisma e comunidade. São Paulo: Madras, 2009.

LACERDA, Gabriel. Nazismo, Cinema e Direito. Rio de Janeiro: Elsevier, 2012.

MÜLLER, Ingo. Hitler's Justice: The Courts of the Third Reich. Cambridge: Harvard University Press, 1992.

MÜLLER, Ingo. Los Juristas del Horror: La justicia de Hitler: El pasado que Alemania no puede dejar atrás. Bogotá: Álvaro Nora, 2009. 
NEUMANN, Franz. A mudança de função da lei no direito da sociedade burguesa. Revista Brasileira de Estudos Políticos, Belo Horizonte. n. 109. p.13-87, jul/dez. 2014.

NEUMANN, Franz. Behemoth: Pensamiento y accion en el Nacional Socialismo. Cidade do México: 1943.

NEUMANN, Franz. O Império do Direito: Teoria Política e Sistema Jurídico na Sociedade Moderna. São Paulo: Quartier Latin, 2010.

NOBRE, Marcos. Curso Livre de Teoria Crítica. Campinas: Papirus, 2008.

RACHLIN, Robert D. Roland Freisler and the Volksgerichtshof: The Court as an a Instrument of Terror. In: STEINWEIS, Alan E; RACHLIN, Robert D. The Law in Nazi Germany: ideology, opportunism and the perversion of justice. Vermont: Berghahn Books, 2013.

RIGG, Bryan Mark. Os soldados judeus de Hitler. Rio de Janeiro: Imago, 2003.

SHIRER, William L. Ascensão e queda do Terceiro Reich. 5. Ed, v. 1. Rio de Janeiro: Civilização Brasileira, 1967.

STACKELBERG, Roderick. A Alemanha de Hitler: origens, interpretações e legados. Rio de Janeiro: In STOLLEIS, Michael. The Law under the Swastika: Studies on Legal History in Nazi Germany. Chicago: The University of Chicago Press, 1998.

WISTRICH, Robert S. Hitler e o Holocausto. Rio de Janeiro: Objetiva, 2002. 